\title{
„Wielka Gra” na Oceanie Indyjskim. Chiny, Indie i Stany Zjednoczone w regionalnej rywalizacji mocarstw
}

\section{WSTĘP}

Ohoć wody Oceanu Indyjskiego stanowią dopiero trzeci co do wielkości basen oceaniczny na świecie, to rosnące znaczenie geopolityczne tego obszaru skupia na sobie coraz większą uwagę wiodących mocarstw światowych. Jego zlewisko od czasów zamierzchłych stanowiło obszar wzmożonej wymiany handlowej oraz miejsce spotkań odmiennych kultur i cywilizacji. Wysoko rozwinięta i niezwykle intensywna żegluga w strefie przybrzeżnej Oceanu Indyjskiego była zasługą silnych i regularnych wiatrów monsunowych, które pozwalały na szybkie i sprawne pokonywanie dużych odległości. Także obecnie wody tego akwenu skupiają ważne dla światowej gospodarki morskie szlaki komunikacyjne, które łączą Bliski Wschód, Afrykę, południową Azję i Australię. Region Oceanu Indyjskiego, jako ważny strategicznie obszar, staje się również polem rywalizacji między wschodzącymi mocarstwami Chin i Indii.

Oba państwa, choć w różny sposób i w różnym tempie, dokonały w ciągu ostatnich dekad ogromnego skoku cywilizacyjnego. Wraz ze wzrostem PKB wschodzące azjatyckie mocarstwa zaczynają wykazywać coraz większą asertywność w zabieganiu o swoje interesy na świecie. Osią rysującej się pomiędzy nimi rywalizacji pozostają kwestie energetyczne oraz odmienne koncepcje polityki bezpieczeństwa w regionie. Nakładają się na to również nieuregulowane spory terytorialne oraz odmienność kulturowa i polityczna. Interesy obu państw, niczym ogromne płyty tektoniczne, coraz częściej ścierają się ze sobą. Proces ten stanowi swoisty katalizator przemian geopolitycznych na kontynencie azjatyckim.

Istotnym czynnikiem wydaje się również silne zaangażowanie Stanów Zjednoczonych, tradycyjnie zainteresowanych azjatyckim obszarem. USA chcą współuczestniczyć w kreowaniu ładu politycznego w jego obrębie. Działania Amerykanów nastawione są przede 
wszystkim na równoważenie rosnących wpływów Chińskiej Republiki Ludowej. Zaangażowanie Stanów Zjednoczonych może zadecydować o ostatecznym wyniku, toczącej się w Azji, gry interesów.

\section{„Petrodyplomacja” W NATARCiU}

FAKTEM JEST, Iż PO BLisko DWUSTU LATACH PRZERWy Azja stopniowo odzyskuje dominującą pozycję w globalnej gospodarce. W pierwszej połowie XIX w. Chiny i Indie wytwarzały ponad połowę globalnego PKB. W latach sześćdziesiątych XX w. udział obu państw w światowej gospodarce spadł poniżej 10 proc., by ponownie przekroczyć poziom 20 proc. w roku 2010. Złożyło się na ten stan rzeczy wiele różnych czynników. Zasadniczym powodem, korzystnej dla Chin i Indii, zmiany w strukturze światowej gospodarki był szybki i nieprzerwany wzrost gospodarczy, notowany w tych państwach w przeciągu ostatnich kilku dekad. Wzrost chińskiego PKB w latach 1980-2010 wyniósł średnio 10 proc. Indie wkroczyły na drogę szybkiego wzrostu nieco później, bo dopiero w pierwszej połowie lat dziewięćdziesiątych. Średnioroczny wzrost gospodarczy Indii w tamtej dekadzie sięgnął blisko 6 proc., a w latach dwutysięcznych osiągnął poziom 8 proc. ${ }^{1}$. Oba państwa obrały przy tym różne modele rozwoju gospodarczego. Chińska gospodarka oparta jest przede wszystkim na produkcji przemysłowej. Jej wzrost jest wynikiem reform zainicjowanych przez Deng Xiaoping'a, które polegały głównie na wykorzystaniu ogromnego potencjału demograficznego ChRL, zapewniającego dużą ilość taniej siły roboczej. W przeciwieństwie do modelu chińskiego, gospodarka Indii oparta jest na usługach i nowoczesnych technologiach, choć produkcja przemysłowa również odgrywa w niej istotną rolę².

Bez względu na odmienną strukturę obu gospodarek ich wspólną cechą, i przy okazji główną słabością, jest wysoka energochłonność. W opinii analityków wielokrotny wzrost cen surowców energetycznych, który nastąpił w ciągu ostatniej dekady, to przede wszystkim zasługa coraz większego popytu zgłaszanego przez Indie i Chiny. W 2004 r. światowe zapotrzebowanie na ropę naftową przekroczyło $75 \mathrm{mln}$ baryłek dziennie. Do 2025 r. nastąpi wzrost do ok. $120 \mathrm{mln}$

${ }^{1}$ Dane na temat wzrostu gospodarczego Chin i Indii ze źródeł Banku Światowego, http://data.worldbank.org/indicator/NY.GDP.MKTP.KD.ZG/countrie, 03.06.2011 r.

${ }^{2} \mathrm{Zob}$. M. Li, The rise of China and the demise of the capitalist world-economy, London 2006; A. Harney, Chińska cena. Prawdziwy koszt chińskiej przewagi konkurencyjnej, Katowice 2009; R. Meredith, The Elephant and the Dragon, New York 2007. 
baryłek dziennie. 80 proc. dodatkowej produkcji trafi na rynki azjatyckie ${ }^{3}$.

W latach 1980-2000 wzrost gospodarczy Chin przekraczał procentowy wzrost zapotrzebowania na energię. Trend odwrócił się w roku 2001, gdy możliwości energetyczne Chin przestały nadążać za prężnie rozwijającą się gospodarką. Istotnym czynnikiem w tym procesie był również wzrost zużycia energii przez chińskie społeczeństwo. Chiny stały się wówczas drugim po Stanach Zjednoczonych konsumentem ropy na świecie oraz trzecim jej importerem (po USA i Japonii) ${ }^{4}$. Choć nadal produkcja energii w Chinach oparta jest przede wszystkim na węglu, to sukcesywnie wzrasta w niej udział ropy i gazu ziemnego $^{5}$. Są to surowce, których niedobór pokrywany jest przede wszystkim poprzez import. W 2008 r. Chiny importowały blisko 45 proc. zużywanej przez siebie ropy. 76 proc. sprowadzanego surowca pochodziło z Zatoki Perskiej oraz Afryki. Sprowadzana ropa naftowa pokrywa ponad 10 proc. ogólnego zapotrzebowania na energię w tym państwie. Długoterminowe oceny wskazują, że udział ten będzie się zwiększać6.

W podobnej sytuacji znajdują się Indie. Państwo to zajmuje obecnie piąte miejsce pod względem spożycia ropy naftowej (po USA, Chinach, Japonii i Korei Południowej). W niedalekiej przyszłości Indie zajmą czwartą pozycję, wyprzedzając Koreę Południową, a nominalne spożycie ropy w tym państwie wyniesie w 2020 r. około 4 mln. baryłek dziennie (obecnie jest to blisko 2,6 mln. baryłek)7. Ponadto Indie, w dużo większym stopniu niż Chiny, uzależnione są od importu surowców energetycznych. Sprowadzają blisko 73 proc. zużywanej przez siebie ropy naftowej. Badania wykonane przez Bombay's Strategic Foresight Group wskazują, że do 2030 r. blisko 90 proc. zużywanego w Indiach surowca pochodzić będzie z zagranicy ${ }^{8}$.

${ }^{3}$ B. Chellaney, Asian Juggernaut: The rise of China, India and Japan, New York 2010, s. 92.

4 Do 1993 r. Chiny były samowystarczalne pod względem energetycznym. Pewna część wytwarzanych surowców była przez nie eksportowana za granicę. W latach 1994-2000 zużycie ropy naftowej skoczyło o 55 proc. zaś jej produkcja wzrosła jedynie o 11 proc. S. Craig, Chinese perceptions of traditional and nontraditional threats, SSI USAWC, March 2007, s. 120.

${ }^{5} \mathrm{O}$ ile w $2001 \mathrm{r}$. Chiny zużywały blisko 1,6 mln. baryłek ropy dziennie to w $2007 \mathrm{r}$. liczba ta wzrosła do poziomu 4,1 mln. baryłek.

${ }^{6}$ E. Medeiros, China's international behavior. Activism, opportunism, and diversification, Santa Monica 2009, s. 39-40.

7 B. Chellaney, Asian Juggernaut..., op. cit., s. 97.

${ }^{8}$ P. Engardio, Chindia: How China and India are revolutionizing global business, 
Rosnące uzależnienie od importu surowców energetycznych nie jest niczym niezwykłym wśród innych państw azjatyckich. Japonia, Korea Południowa oraz Republika Chińska na Tajwanie zmuszone są obecnie do importu całości zużywanej przez siebie ropy naftowej’. Jednak w przeciwieństwie do nich gospodarki Chin i Indii są dużo bardziej energochłonne. Ocenia się, że wyprodukowanie 1 dol. Produktu Krajowego Brutto w tych państwach wymaga zużycia trzy razy większej ilości energii niż przewiduje to średnia światowa ${ }^{10}$. Indie i Chiny nie posiadają drogich technologii energooszczędnych, a wszelkie próby zmniejszenia zużycia energii mogłyby pozbawić ich gospodarki przewagi konkurencyjnej tak potrzebnej dla dalszego szybkiego wzro$\mathrm{stu}^{11}$.

Ponadto Indie i Chiny, w przeciwieństwie do Japonii czy Korei Południowej, starają się pozyskiwać surowce energetyczne bezpośrednio u producenta, a nie za pośrednictwem rynków światowych. Fakt ten ma daleko idące konsekwencje polityczne. Agresywna działalność inwestycyjna dużych państwowych koncernów energetycznych wspierana jest działaniami dyplomatycznymi, jak również środkami militarnymi. Przyjmując, że rynek surowców energetycznych będzie się sukcesywnie kurczył wraz z czerpaniem się światowych zasobów, przy jednoczesnym zwiększającym się popycie, oba państwa dążyć będą do zapewnienia sobie gwarancji długoterminowych i nieprzerwanych dostaw o wysokim stopniu dywersyfikacji. Zjawisko to nazwane „petrodyplomacją" stanowi obecnie istotny czynnik kształtujący stosunki międzynarodowe na kontynencie azjatyckim.

Rywalizacja Chin i Indii o dostęp do źródeł surowców energetycznych toczy się w różnych, często niestabilnych politycznie, regionach świata. Jest to przede wszystkim Zatoka Perska, Afryka oraz Azja Południowowschodnia i Centralna. Strategia obu państw polega głównie na wykupywaniu koncesji i praw do eksploatacji złóż w państwach bogatych w surowce, lecz nie posiadających wystarczająco rozwiniętego przemysłu wydobywczego, by samodzielnie je eksportować. Najbardziej atrakcyjne są pod tym względem państwa, w których zachodnie koncerny energetyczne, przeważnie ze względów politycznych,

New York 2007, s. 318.

${ }^{9}$ B. Chellaney, Asian Juggernaut..., op. cit., s. 97.

${ }^{10}$ P. Engardio, Chindia: How China and India..., op. cit., s. 313.

${ }^{11}$ Wiąże się to również z kwestią kosztów ograniczenia emisji dwutlenku węgla do atmosfery. Oba państwa konsekwentnie odmawiają nałożenia na siebie limitów, które ograniczyłyby ich rozwój gospodarczy. 
nie chcą bądź nie mogą inwestować. Iran, Sudan, Czad czy Birma ${ }^{12}$ to tylko kilka przykładów. Państwowe koncerny energetyczne Chin i Indii, których nadrzędnym celem jest zapewnienie stałych dostaw surowców, oferują najczęściej bardzo korzystne warunki eksploatacji, godząc się na wysokie opłaty koncesyjne ${ }^{13}$. Koncernom zachodnim coraz trudniej konkurować pod tym względem z państwowymi gigantami z Azji, takimi jak chińskie CNPC (China National Petroleum Corporation) oraz CNOOC (China National Offshore Oil Corporation) oraz hinduska ONGC (Oil and Natural Gas Corporation) ${ }^{14}$.

W celu pozyskania wyłącznych praw na wydobycie oraz import surowców oba państwa do oferty gospodarczej dołączają często ofertę polityczną. Umowom energetycznym towarzyszą umowy o współpracy wojskowej czy sprzedaży uzbrojenia. Dla takich państw jak Sudan, Birma czy Iran nie bez znaczenia pozostaje również fakt posiadania przez Chiny statusu stałego członka Rady Bezpieczeństwa ONZ z prawem weta $^{15}$. Tak wpływowy sojusznik jest w stanie zapewnić tym państwom parasol ochronny w zamian za prawo eksploatacji swoich zasobów naturalnych. Najlepszą ilustracją tej praktyki jest przykład chińskich inwestycji w Sudanie. ChRL oskarżana jest, iż w zamian za koncesje na eksploatację złóż naftowych dostarczała do Sudanu uzbrojenie, które wykorzystywane było w wojnie domowej na południu kraju, a także w Darfurze, na którym ciąży embargo RB ONZ. Blokowała również niektóre inicjatywy społeczności międzynarodowej zmierzające do rozszerzenia katalogu sankcji nałożonych na to państwo ${ }^{16}$.

${ }^{12}$ Grupa tych państw w literaturze anglojęzycznej często określana jest mianem $p a-$ riah states lub rogue states. W polskiej terminologii funkcjonuje określenie „państw zbójeckich”. Według Włodzimierza Malendowskiego państwa te „stosują przemoc wobec własnych obywateli i wykorzystują zasoby naturalne kraju dla prywatnych korzyści rządzących; okazują brak szacunku dla prawa międzynarodowego, grożą państwom ościennym i cynicznie łamią traktaty międzynarodowe, których są stroną; (...) wspierają terroryzm na całym świecie; odrzucają podstawowe wartości ludzkie i nienawidzą Stanów Zjednoczonych (...)”. Leksykon wspótczesnych międzynarodowych stosunków politycznych, red. C. Mojsiewicz, Wrocław 2007, s. 300.

${ }_{13}$ R. Meredith, The Elephant..., op. cit., s. 159-188; B. Chellaney, Asian Juggernaut..., op. cit., s. 104-105.

${ }^{14}$ Por. F. Leverett, J. Bader, Managing China-U.S. energy competition in the Middle East, „The Washington Quarterly”, vol. 29, no. 1 (Winter 2005-06), s. 187-201; K. Morrison, China and India raise the stakes, „Financial Times” z 08.01.2005 r..

${ }^{15}$ B. Chellaney, Asian Juggernaut..., op. cit., s. 95.

${ }^{16}$ Zob. P. Goodman, China invests heavily in Sudan's oil industry. Beijing supplies arms used on villagers, „The Washington Post” z 23.12.2004 r.. 
W zgodnej opinii większości ekspertów, w wyścigu po surowce to Chiny znajdują się na czele stawki. Państwo to dysponuje ogromnymi rezerwami finansowymi oraz chętnie posługuje się swoimi wpływami politycznymi na świecie. Indie mają w tym względzie dużo mniejsze pole manewru. Nie ustają jednak w staraniach na rzecz zapewnienia sobie bezpieczeństwa energetycznego. Przykładem determinacji Indii był projekt budowy gazociągu biegnącego z Iranu przez terytoria Afganistanu i Pakistanu, aż do prowincji Radżastan w północno-zachodniej części kraju ${ }^{17}$. Przedsięwzięcie, obarczone ogromnym politycznym i ekonomicznym ryzykiem, miało być czynnikiem cementującym stosunki indo-irańskie, których zasadniczą treścią pozostaje współpraca energetyczna. Gazociąg pozwoliłby na uwolnienie ogromnych rezerw gazu ziemnego w Iranie i doprowadził do wzmocnienia tego państwa. Indie rozwijały dobre relacje z Iranem także poprzez współpracę wojskową i wywiadowczą ku niezadowoleniu swoich najbliższych sojuszników w USA i Izraelu ${ }^{18}$.

Iran posiada drugie co do wielkości rezerwy gazu ziemnego na świecie. Nie posiada jednak możliwości jego eksportu. Polityka Stanów Zjednoczonych zmierza do pozbawienia Iranu możliwości czerpania korzyści z surowców naturalnych. Promowane przez USA sankcje wobec Iranu związane są z prowadzonym przez to państwo programem jądrowym. Indie zmuszone są do balansowania pomiędzy interesami USA w regionie oraz własnym interesem energetycznym. Indo-irańskie projekty energetyczne naruszają zapisy amerykańskiej ustawy nakładającej sankcje na Libię i Iran z 1992 r. (ILSA - Iran-Libya Sanction Act). Fakt ten podważa zasadność rysującego się sojuszu ze Stanami Zjednoczonymi, jak również może doprowadzić do skierowania ostrza amerykańskich sankcji także w Indie ${ }^{19}$. Należy jednak pamiętać, iż ewentualne odstąpienie Indii od współpracy energetycznej z Iranem skutkować będzie jedynie umocnieniem pozycji Chin w tym państwie.

Całościowy obraz rywalizacji o dostęp do surowców energetycznych na kontynencie azjatyckim dopełniają odżywające $\mathrm{z}$ nową siłą spory graniczne dotyczące terytoriów zasobnych w węglowodory.

${ }^{17}$ P. Engardio, Chindia: How China..., op. cit., s. 318-319.

${ }^{18}$ C. Fair, Indo-Iranian security ties: Thicker than oil, „Middle East Review of International Affairs", vol. 11, no. 1 (March 2007), s. 41-53.

${ }^{19}$ B. Chellaney, Asian Juggernaut..., op. cit., s. 115-116; S. Blank, Natural allies? Regional security in Asia and prospects for indo-american strategic cooperation, USAWC ISS, September 2005, s. 29-33, 40-41. 
Najbardziej zapalnymi punktami po tym względem są baseny Mórz Południowochińskiego i Wschodniochińskiego. Chiny roszczą sobie prawo do określonych obszarów tych akwenów, powołując się przy tym na względy historyczne. W 1992 r. uchwalono w Chinach ustawę, na mocy której uznano wyłączne prawo tego państwa do prawie 4/5 powierzchni Morza Południowochińskiego, w tym spornych wysp Spratly oraz wysp Paracelskich. Obszary te zasobne są w ropę naftową. Prawa do nich roszczą sobie także Wietnam oraz Republika Chińska na Tajwanie ${ }^{20}$. Podobny spór ChRL toczy z Japonią w sprawie archipelagu wysp Senkaku (Diaoyu) na Morzu Wschodniochińskim² ${ }^{21}$

W 1987 r. i 1988 r. doszło do starć zbrojnych na wodach wysp Spratly pomiędzy jednostkami chińskiej i wietnamskiej marynarki wojennej ${ }^{22}$. Od tego czasu na spornych obszarach dochodzi najwyżej do incydentów niegroźnych w skutkach. Choć strony sporu wykazują chęć jego pokojowej regulacji, to nie można wykluczyć, iż w obliczu coraz trudniejszej sytuacji na rynku surowcowym może dojść do zaostrzenia tych konfliktów. W tym kontekście warto przytoczyć opinię Henry'ego Kissingera, w której ostrzega przed wybuchem światowego konfliktu na tle energetycznym ${ }^{23}$. Wraz z rosnącym zapotrzebowaniem na surowce widmo takiego konfliktu nabrać może realnego wymiaru. Taka perspektywa dotyczy szczególnie Azji Południowej i Południowowschodniej.

\section{Strategia „Sznura Peree”}

Rosnąe UZALEŻNiENIE CHIN I INDII OD SURowCów NATURALNYCH pochodzących z importu zmusza oba te państwa do sprowadzania ich z bardzo odległych regionów świata. Dominują w tym względzie państwa Zatoki

${ }^{20}$ Prawo do administrowania pojedynczymi wyspami roszczą sobie również Filipiny oraz Malezja. B. Chellaney, Asian Juggernaut..., op. cit., s. 99; E. Haliżak, Spór o archipelagi na Morzu Południowochińskim - znaczenie dla międzynarodowego prawa morza i bezpieczeństwa $w$ regionie, [w:] Prawo, instytucje i polityka $w$ procesie globalizacji. Księga jubileuszowa dedykowana Profesorowi Januszowi Simonidesowi, red. E. Haliżak, R. Kuźniar, Warszawa 2003, s. 174-193.

${ }^{21}$ Zob. K. Kubiak, Incydent na wodach wysp Senkaku, „Raport-wto” 2010, nr 11, s. 72-76.

${ }^{22}$ Starcie zbrojne z 1988 r. na wodach wysp Spratly doprowadziło do poważnych strat w ludziach i sprzęcie po stronie wietnamskiej. Zdarzenie, nazywane przez Wietnam „chińską masakrą”, stanowiło najpoważniejsze starcie zbrojne pomiędzy oboma państwami od czasu wojny z 1979 r. O. Saleem, The Spratly Islands dispute. China defines the New Millennium, „American University International Law Review” 2000, vol. 15 , no. 3 , s. 540 .

${ }^{23}$ C. Daniel, Kissinger warns of energy conflict, „Financial Times” z 02.06.2005 r.. 
Perskiej oraz niektóre państwa afrykańskie. Transport węglowodorów z tych miejsc odbywa się przede wszystkim drogą morską. Fakt ten ma ogromne znaczenie geostrategiczne. Morskie linie komunikacyjne (SLOC ${ }^{24}$ ) przebiegające przez wody Oceanu Indyjskiego skupiają na sobie coraz większą uwagę azjatyckich potęg ze względu na ich znaczenie dla bezpieczeństwa energetycznego. Najważniejsze arterie komunikacyjne skupione na tym akwenie narażone są na szereg zagrożeń mogących zakłócić lub uniemożliwić swobodę żeglugi. Odcięcie państw azjatyckich od dostaw surowców naturalnych mogłoby doprowadzić do całkowitego paraliżu ich gospodarek.

Widmo blokady surowcowej stanowi istotny czynnik, który skłania państwa azjatyckie do ciągłego inwestowania w rozwój i modernizację sił zbrojnych, w szczególności marynarki wojennej. Oficjalny budżet obronny Chin w 2010 r. wyniósł 78 mld. dol. Biorąc pod uwagę brak pełnej transparentności ChRL w tym względzie ośrodek SIPRI ocenia, iż realny budżet wojskowy tego państwa zamyka się w kwocie 119 mld. dol. W latach 2001-2010 procentowy wzrost chińskich wydatków obronnych wyniósł 189 proc., dając średnioroczny wzrost rzędu 12,5 proc. W sumie w tym okresie Chiny wydawały rocznie na ten cel sumy odpowiadające od 2 do 2,2 proc. ich PKB. Jednym z priorytetów w procesie modernizacji chińskich sił zbrojnych jest rozwój marynarki wojennej. Doktryna morska Armii Ludowo-Wyzwoleńczej nadal skupia się głównie na działaniach w obrębie Cieśniny Tajwańskiej, jednak Chiny coraz wyraźniej dążą do budowy floty oceanicznej zdolnej do projekcji siły daleko poza swoje granice ${ }^{25}$.

Dla porównania Indie w 2010 r. wydały na swoje siły zbrojne sumę 41,3 mld. dol., czyli blisko 54 proc. więcej niż w roku 2001. W latach 2001-2010 budżet wojskowy pochłaniał w tym państwie 2-3 proc PKB. Dla Indii rozwój floty wojennej ma szczególne znaczenie. Należy pamiętać, że granica morska Indii kontynentalnych rozciąga się na długości 5,5 tys. km. Wymaga ona więc odpowiedniego zabezpieczenia. Dochodzi do tego rosnące wyzwanie ze strony Chin, które coraz śmielej zaznaczają swoją obecność w strefie przybrzeżnej Oceanu Indyjskiego ${ }^{26}$.

Dla obu państw sprawą o znaczeniu strategicznym jest posiadanie zdolności militarnych pozwalających na kontrolę morskich arterii ko-

${ }^{24}$ SLOC - Sea Lines Of Communications.

${ }_{25}$ SIPRI Yearbook 2011: Armaments, Disarmament and International Security, Oxford 2011, s. 159-161.

${ }^{26}$ Ibidem, s. 166-170. 
munikacyjnych biegnących z Bliskiego Wschodu i Afryki. Wagę tego problemu ilustruje fakt, iż pochodzi stamtąd ponad 70 proc. importowanej przez Chiny ropy naftowej. Sprowadzany surowiec przepływa przez morskie szlaki komunikacyjne na Oceanie Indyjskim takich jak cieśnina Ormuz, Zatoka Omańska, cieśnina Bab al-Mandab, Zatoka Adeńska. By dotrzeć do Chin koniecznym jest również przejście przez Cieśninę Malakka. Ponad 80 proc. importowanych przez ChRL surowców przechodzi przez tą arterię ${ }^{27}$. Akweny te nęka obecnie problem piractwa morskiego. Ponadto znajdują się one w obrębie niestabilnych politycznie regionów. Są również niezwykle zatłoczone i narażone na blokadę ze strony innych państw. Warto dodać, że handel zagraniczny, będący zasadniczym fundamentem chińskiej gospodarki, odbywa się w największym stopniu za pośrednictwem żeglugi morskiej. Przez Ocean Indyjski przechodzi prawie całość chińskiego eksportu do Europy, co w jeszcze większym stopniu podkreśla jego ogromne znaczenie dla gospodarki tego państwa ${ }^{28}$.

Szczególnie problematyczna dla Chin, jak również innych państw azjatyckich, jest kwestia piractwa morskiego. Dotyczy ona przede wszystkim wód somalijskich, Zatoki Adeńskiej oraz cieśniny Malakka. Samo zjawisko, w tym jego geneza, są bardzo złożone. Źródeł współczesnego piractwa morskiego należy upatrywać przede wszystkim w biednych i niestabilnych państwach strefy przybrzeżnej Oceanu Indyjskiego. Proceder ten w istotny sposób zakłóca handel światowy, powodując znaczne straty finansowe oceniane na 16 mld. dol. rocznie. Dla państw azjatyckich istotnym jest również fakt, iż piractwo wydatnie wpływa na światowe ceny ropy naftowej. W latach 2002-2009 zanotowano na świecie ponad 2,5 tys. aktów piractwa morskiego. W latach 2004-2008 nastąpił wyraźny spadek liczby ataków, głównie ze względu na wzrost patroli morskich wykonywanych przez powoływane w tym celu koalicje państw. Jednak w 2009 r. liczba aktów piractwa zwiększyła się o 39 proc. w stosunku do roku poprzedniego (406

${ }^{27}$ C. Pehrson, String of pearls: meeting the challenge of China's rising power across the Asian littoral, USAWC ISS, July 2006, s. 5-7.

${ }^{28}$ Chiński eksport oraz import w prawie 90 proc. uzależnione są od transportu morskiego. Żegluga oraz przemysł stoczniowy odpowiadają za 10 proc. chińskiego PKB. Przeszło 40 proc. statków na Oceanie Indyjskim pływa pod chińską banderą. Zarejestrowano pod nią największą na świecie liczbę jednostek. R. Kamphausen, D. Lai, A. Scobell, The PLA at home and abroad: assessing the operational capabilities of China's military, USAWC ISS, June 2010 s. 298. 
incydentów $)^{29}$. Pokazuje to, że mimo wysiłków społeczności międzynarodowej problem ten nadal daleki jest od rozwiązania.

Mając na względzie ochronę własnych interesów w 2008 r. ChRL wysłała w rejon Zatoki Adeńskiej zespół okrętów wojennych. Po raz pierwszy tak duży komponent chińskiej marynarki wojennej (dwa niszczyciele oraz okręt zaopatrzenia) został wyprawiony poza Azję. Okręty miały przede wszystkim prowadzić działania patrolowe na rzecz zwiększania bezpieczeństwa żeglugi morskiej ${ }^{30}$. Decyzja ta miała również duże znaczenie polityczne. Była swoistym sygnałem dla świata świadczącym, że Chiny nie zamierzają biernie przyglądać się problemom bezpieczeństwa w obrębie Oceanu Indyjskiego. W tym wypadku Chiny uniknęły błędów z lat 2003-04. W tamtym okresie najbardziej narażona na ataki piratów była cieśnina Malakka wraz z okolicznymi akwenami. Wobec biernej postawy Chin inicjatywę przejęły Stany Zjednoczone, pod naciskiem których zorganizowano patrole morskie na tym obszarze. Początkowo były one złożone głównie z jednostek państw cieśninowych (Malezja, Singapur, Indonezja). Z czasem do koalicji przyłączyły się Tajlandia, Australia, Nowa Zelandia, Wielka Brytania oraz Indie. Ma ona również silne polityczne wsparcie organizacji ASEAN $^{31}$.

Cieśnina Malakka stanowi obecnie największe wyzwanie dla chińskich strategów. Ta, łącząca dwa oceany, arteria morska przyjmuje rocznie ponad 50 tys. dużych jednostek handlowych w tym 40-50 tankowców z ropą naftową dziennie ${ }^{32}$. Tak duże natężenie ruchu grozi częstymi kolizjami oraz katastrofą ekologiczną. Jednak Chiny, przy braku alternatywnych przejść, są od cieśniny w pełni uzależnione. Problem ten nazywany jest w Chinach „dylematem Malakka”. Duży niepokój w Pekinie budzi również możliwość blokady cieśniny przez Indie. Państwo to posiada na Morzu Andamańskim rozbudowany system baz wojskowych nazwany „Żelazną Kurtyną”. Dzięki niemu Indie są w stanie kontrolować wejście do cieśniny. Hindusi dysponują rozległą infrastrukturą zdolną do sparaliżowania tej, strategicznej dla Chin, arterii

${ }^{29}$ Z. Śliwa, D. Brążkiewicz, Piractwo wyzwaniem dla bezpieczeństwa, „Kwartalnik Bellona" 2010, nr 2, s. 17-19.

${ }^{30}$ Z. Śliwa, Marynarka Wojenna Chin w walce z piratami, „Przegląd Morski” 2010, nr 7, s. 6-7.

${ }^{31}$ Z. Śliwa, D. Brążkiewicz, Piractwo wyzwaniem..., op. cit., s. 22.

${ }^{32} \mathrm{R}$. Czulda, Nowe wyzwania i zagrożenia na obszarach morskich, „Przegląd Morski” 2009, nr 1, s. 41. 
komunikacyjnej. Strategia „Żelaznej Kurtyny” stanowi dla ChRL źródło szczególnego niepokoju ${ }^{33}$.

W odpowiedzi na to zagrożenie Chiny tworzą system zabezpieczenia logistycznego wzdłuż strefy przybrzeżnej Oceanu Indyjskiego. Chińska strategia polega na rozbudowywaniu morskiej infrastruktury portowej w państwach przybrzeżnych tej strefy. Wyspa Hajnan na Morzu Południowochińskim kryje w sobie bazę atomowych okrętów podwodnych. Wyspa Woody Island, będąca częścią spornego archipelagu Paraceli, posiada dużą bazę lotniczą. W Zatoce Bengalskiej ChRL posiada porty oraz stacje paliwowe w Chittagong (Bangladesz) i Sittwe (Birma) oraz lotnisko i stacją radarową na Wyspach Kokosowych (Birma). Na Sri Lance znajduje się chiński port w Hambantota. Podobna infrastruktura znajduje się u wybrzeży Kenii na wyspie Lamu. Miejsca te, nazywane „Sznurem Pereł”, stanowią chińskie przyczółki na Oceanie Indyjskim. Symbolizują postępującą ekspansję wpływów tego państwa w regionie ${ }^{34}$.

Najcenniejszą inwestycją ChRL na Oceanie Indyjskim, zaliczaną do tzw. „Sznura Perel”, jest nowoczesny port morski w pakistańskim mieście Gwadar. Miejsce to jest usytuowane u wylotu Zatoki Omańskiej i stanowi, ważny strategicznie, chiński przyczółek na Morzu Arabskim. Inwestycja rozpoczęła się w 2004 r. i była możliwa dzięki bliskim stosunkom z Pakistanem. W 2007 r. zakończył się pierwszy etap budowy, w rezultacie którego Gwadar zyskał nowoczesną infrastrukturę portową zdolną do przyjmowania jednostek handlowych o tonażu powyżej 50 tys. ton, jak również dużych okrętów wojennych. Chiny mają wobec tej inwestycji dalsze plany. Kolejne jej etapy przewidują budowę rafinerii oraz, biegnącego przez masyw górski Karakorum, ropociągu do ChRL. Pozwoliłoby to na częściowe zredukowanie morskiego odcinka transportu importowanego do Chin surowca i ominięcie problematycznych arterii ${ }^{35}$. Gwadar mógłby również uzyskać status „morskiej bramy” Azji Centralnej dzięki budowie sieci rurociągów, autostrad i linii kolejowych łączących to miejsce z zasobnymi w surowce Kazachstanem i Turkmenistanem. Plany te wstrzymuje jednak niesta-

${ }^{33}$ S. Niedziela, Indie - nowe mocarstwo światowe, „Przegląd Morski” 2009, nr 6, s. 9; R. Rai, China's String of Pearls vs India's Iron Curtain, „Indian Defence Review” 2009, vol. 24, no. 4, http://www.indiandefencereview.com/geopolitics/Chinas-Stringof-Pearls-vs-Indias-Iron-Curtain.html, 12.05.2011 r.

34 C. Pehrson, String of pearls..., op. cit., s. 3-4.

35 Analogiczny plan Chiny realizują wobec inwestycji portowej w Birmie. 
bilna sytuacja polityczna w Pakistanie, w tym rebelia w prowincji Beludżystan, na której obszarze znajduje się miasto portowe ${ }^{36}$.

Port w Gwadar budzi ogromny niepokój w Indiach. Choć jest to inwestycja komercyjna, to umieszczona w Pakistanie infrastruktura portowa zdolna jest do przyjmowania dużych zespołów floty wojennej. Dzięki niej chińska marynarka uchwyciła dla siebie cenny punkt bazowania manewrowego na zachód od półwyspu Dekan. Korzyści z portu odnosi również marynarka pakistańska zdolna dzięki niemu do przebazowania swoich sił na zachód. Do tej pory siły morskie Pakistanu uzależnione były od portu w Karaczi, który w 1971 r. z łatwością został zablokowany przez flotę hinduską. W ocenie Indii chiński port w Pakistanie narusza równowagę militarną $\mathrm{w}$ regionie ${ }^{37}$. Nie ulega wątpliwości, iż zwiększona aktywność chińskiej floty w strefie przybrzeżnej Oceanu Indyjskiego w dłuższej perspektywie podważy dotychczasową dominację Indii na tym basenie.

Indie traktują Ocean Indyjski jako swoiste mare nostrum, starając się odgrywać na nim rolę jedynego mocarstwa. Państwo to nie jest w stanie wygrać rywalizacji z Chinami na kontynencie. Skupia się więc na zdobyciu hegemoni oceanicznej na całej przestrzeni Oceanu Indyjskiego - od Afryki po Australię, od cieśniny Ormuz po cieśninę Malakka i od Sri Lanki po Antarktydę. Doktrynę tą sformułował Jawaharlal Nehru, który dominację na oceanie uznał wręcz za niezbędny warunek dla zachowania niepodległości Indiii ${ }^{38}$. Głównym instrumentem służącym w tym celu jest hinduska marynarka wojenna. Stanowi ona obecnie wiodącą siłę militarną w regionie. Jednak przez długi czas to wojska lądowe posiadały priorytet w całych siłach zbrojnych. Była to konsekwencja konfliktów zbrojnych z Chinami (1962 r.) oraz Pakistanem (1965 r., 1971 r.). Sytuacja uległa zmianie w drugiej połowie lat dziewięćdziesiątych, gdy zaczęto inwestować w rozwój floty oceanicznej. Budżet na ten cel wzrósł z 1,3 mld dol., a w 2001 r. do poziomu 3,5 mld dol. w roku 2006. Do 2020 r. w skład floty wojennej Indii ma wchodzić ponad 130 okrętów różnych typów i klas. Jej trzonem mają być trzy lotniskowcowe grupy uderzeniowe. Indie posiadają obecnie jeden okręt lotniczy INS Viraat otrzymany od Wielkiej Brytanii w 1987 r. (dawny HMS Hermes). W 2004 r. zakupiono poradziecki okręt Admirał Gorszkow (klasa Kijów), który poddawany jest rewitali-

${ }^{36}$ K. Kubiak, Gwadar - pakistański problem ChRL, „Raport-wto” 2010, nr 3, s. $70-71$.

${ }^{37}$ Ibidem.

${ }^{38}$ J. Nehru, Odkrycie Indii, Warszawa 1957, s. 536. 
zacji. Ponadto w stoczni Cochin trwają prace nad własną konstrukcją lotniskowca klasy Vikrant ${ }^{39}$.

Chiny również aspirują do posiadania własnych lotniskowców. Według oficjalnych informacji prace nad pierwszym z nich znajdują się $\mathrm{w}$ wysokim stadium zaawansowania ${ }^{40}$. Państwo to posiada finansowy i przemysłowy potencjał pozwalający na samodzielną budowę i eksploatację okrętów tego typu. Dzięki nim chińska marynarka wojenna umocniłaby swoją pozycję na przylegających do Chin akwenach, w tym na wodach cieśniny tajwańskiej. Miałoby to poważne konsekwencje dla Stanów Zjednoczonych, których dominacja w tej części świata uległaby znacznemu osłabieniu. Własne lotniskowce pozwoliłyby również wkroczyć chińskiej flocie na wody Oceanu Indyjskiego w celu lepszego zabezpieczenia dostępu do morskich linii komunikacyjnych na tym basenie ${ }^{41}$.

Lotniskowce to tradycyjne narzędzia morskiej projekcji siły. Wschodzące mocarstwa Chin i Indii sukcesywnie wchodzą w posiadanie tego typu systemów uzbrojenia dzięki wysokiemu wzrostowi gospodarczemu. Przełamują pod tym względem dotychczasową dominację Stanów Zjednoczonych i kilku państw europejskich. Pływające po morzach i oceanach duże okręty lotnicze należące do obu państw stanowią istotny symbol wzrostu ich siły i znaczenia na świecie. Jest to również swoisty renesans klasycznej koncepcji nawalizmu Alfreda T. Mahana, która zakłada budowę nowoczesnej marynarki wojennej w celu ochrony floty handlowej, gdyż oba te elementy w połączeniu decydują o potędze państwa ${ }^{42}$. Fakt ten budzi jednocześnie niepokój wśród tradycyjnych potęg światowych. Rosnący potencjał wojskowy

${ }^{39}$ J. Holslag, China, India and the military security dilemma, „BICCS Asia Paper”, vol. 3 , no. 5 , s. 14-15.

${ }^{40} \mathrm{~W}$ kwietniu 2011 r. państwowa agencja informacyjna Xinhua ujawniła wstępne informacje na temat przyszłego chińskiego lotniskowca. Pokazano zdjęcia ukazujące prace nad okrętem prowadzone w stoczni Dalian. Zgodnie z przewidywaniami ekspertów kadłub lotniskowca stanowi, zakupiony w 1998 r. na Ukrainie, poradziecki okręt lotniczy Wariag (klasa Admirał Kuzniecow). Okręt powinien wejść do służby i osiągnąć pełną zdolność operacyjną przed 2015 r. Jego ujawnienie zbiegło się w czasie z wizytą amerykańskiego Sekretarza Obrony Roberta Gatesa w Pekinie. E. Wong, Chinese warship may be nearly ready, „New York Times” z 08.04.2011 r.

${ }^{41}$ Por. D. Lai, Chinese military going global, „China Security” 2009, vol. 5, no. 1, s. 7.

${ }^{42} \mathrm{~W}$ swoich pracach A.T. Mahan rozwój potęgi morskiej państwa uzależnił od posiadania narzędzi lądowej projekcji siły, w tym zdolności desantowych. Podkreślał również konieczność posiadania strategicznych baz morskich oraz rozbudowanego zaplecza lądowego. Zob. C. Jean, Geopolityka, Wrocław-Warszawa-Kraków 2003, s. 75. 
Chin i Indii stanowi bowiem główny czynnik wpływający na intensyfikację wyścigu zbrojeń na całym kontynencie azjatyckim. Dotknięte kryzysem mocarstwa zachodnie, w tym Stany Zjednoczone, moga nie być w stanie za nim nadążyć. Zjawisko spirali zbrojeń może ponadto doprowadzić do destabilizacji sytuacji w regionie.

\section{STANY ZJEDNOCZONE - GASNĄCE MOCARSTWO?}

WZROST POTĘG GOSPODARCZEJ PAŃSTW AZJATYCKICH, głównie Chin i Indii, niesie ze sobą jednocześnie szereg głębokich zmian geopolitycznych w tej części świata. Państwa te sukcesywnie nabywają zdolności transformacji ogromnego potencjału gospodarczego w siłę polityczno-wojskową, zdolną do kształtowania sytuacji międzynarodowej zgodnie ze swoimi interesami. Zmiany te w szczególny sposób odczuwają Stany Zjednoczone - mocarstwo globalne tradycyjnie zainteresowane tym obszarem. Jest ono związane z państwami regionu szeregiem sojuszy oraz istotnymi interesami gospodarczymi ${ }^{43}$. Z perspektywy amerykańskiej największy niepokój budzi rosnąca pozycja Chin, które wykazują coraz większą asertywność w zabieganiu o swoje interesy. Również małe i średnie państwa regionu dostrzegają ten problem. Osłabione kryzysem gospodarczym Stany Zjednoczone nie będą w stanie utrzymać samodzielnej dominacji w Azji. Są jednak w stanie opóźnić proces jej utraty poprzez budowę sojuszy ukierunkowanych na powstrzymanie chińskich ambicji.

Zaangażowanie USA na kontynencie azjatyckim wyraża się przede wszystkim poprzez obecność amerykańskiej marynarki wojennej na wodach zachodniego Pacyfiku oraz Oceanu Indyjskiego. Zwycięstwo nad Japonią w drugiej wojnie światowej przyniosło Stanom Zjednoczonym niemal totalną dominację pod tym względem. Amerykańska marynarka wojenna stanowiła wówczas niezrównaną siłę, której nie był w stanie dorównać nawet Związek Radziecki przez cały okres swojego istnienia. Bezpośrednio po wojnie USA posiadały ponad 6 tys. okrętów wojennych. W okresie zimnowojennym ilość ta utrzymywała się na poziomie 600 okrętów. W latach dziewięćdziesiątych było to ponad 350 okrętów. Obecnie liczba ta oscyluje wokół 280 jednostek,

${ }^{43}$ Należy w tym względzie wymienić przede wszystkim Japonię, Koreę Południową oraz Republikę Chińską na Tajwanie. Stany Zjednoczone zawarły z tymi państwami umowy o współpracy polityczno-wojskowej. W Japonii i Korei Południowej stacjonują na stałe wojska amerykańskie. C. Mojsiewicz, Państwa regionu Pacyfiku $w$ polityce i gospodarce światowej, [w:] Stosunki międzynarodowe, red. W. Malendowski, C. Mojsiewicz, Wrocław 2004, s. 112-115. 
w tym jedenastu lotniskowcowych grup uderzeniowych. Choć dane te ukazują postępujące kurczenie się amerykańskiej floty wojennej to nadal stanowi ona siłę nieporównywalną z żadnym innym państwem ${ }^{44}$. Jednak w obliczu kryzysu gospodarczego, którego konsekwencją jest długoterminowa redukcja budżetu obronnego, Stany Zjednoczone muszą się liczyć z rosnącą konkurencją ze strony nowych potęg morskich takich, jak Chiny czy Indie.

Według amerykańskiego Biura Wywiadu Marynarki (ONI) Chiny w bardzo szybkim tempie modernizują swoje siły morskie. Udział nowoczesnych jednostek we flocie okrętów podwodnych w $2000 \mathrm{r}$. wynosił mniej niż 10 proc. W 2008 r. udział ten urósł do poziomu 47 proc., a w 2009 r. przekroczył 50 proc. Podobnie sytuacja wygląda w stosunku do okrętów nawodnych. Nowoczesne konstrukcje w 2000 r. również stanowiły zaledwie 10 proc. całości floty, by w roku 2009 osiągnąc poziom ponad 25 proc. Biuro ocenia, że do 2020 r. marynarka wojenna ChRL osiągnie rozmiar prawie 150 okrętów, a liczba maszyn użytkowanych przez lotnictwo morskie ulegnie potrojeniu ${ }^{45}$. Liczby te są wysoce alarmujące dla amerykańskich strategów. Stanom Zjednoczonym coraz trudniej będzie dotrzymywać zobowiązań sojuszniczych wobec niektórych państw regionu. W największym stopniu dotyczy to Tajwanu, który nadal stanowi najbardziej drażliwy aspekt stosunków amerykańsko-chińskich.

Odpowiedzią amerykańskich sił zbrojnych na rosnące wyzwanie stawiane ze strony Chin jest, zainicjowany w 2001 r. program budowy okrętów typu LCS (Littoral Combat Ship). Przewiduje on budowę niedużych, szybkich, zwrotnych i trudno wykrywalnych okrętów przeznaczonych do operowania na wodach litoralnych (przybrzeżnych). Jest to największy od wielu lat program zbrojeniowy amerykańskiej marynarki. Okręty nowego typu, dzięki modułowej budowie, mogą być szybko przystosowywane do wykonywania różnych zadań niezależnie od miejsca. Ich wielozadaniowość oznacza, że okręty te dostosowane mogą być do prowadzenia całej gamy zadań i misji: działań patrolowych, logistycznych, rozpoznawczych, zwalczania min, zwalczania jednostek podwodnych i nawodnych. Okręty typu LCS będą miały

${ }^{44}$ R. Kaplan, Monsoon: The Indian Ocean and the future of American power, New York 2010, s. 277-278.

45 R. O’Rourke, China naval modernization: Implications for U.S. Navy capabilities-background and issues for Congress, Congressional Research Service Report RL33153, Washington DC, 22 April 2011, s. 38-40. http://www.fas.org/sgp/crs/row/ RL33153.pdf, 10.06.2011 r.. 
także istotny udział w przeciwdziałaniu zagrożeniom asymetrycznym na morzu takim, jak terroryzm, piractwo czy przemyt ${ }^{46}$. Realizacja tego oraz innych programów zbrojeniowych pozwoli amerykańskiej marynarce na dłużej utrzymać pozycję lidera na wodach zachodniego Pacyfiku i Oceanu Indyjskiego ${ }^{47}$.

Rola amerykańskich sił morskich w tej części świata nie ogranicza się jedynie do projekcji siły militarnej. Ważnym zadaniem jest również niesienie pomocy humanitarnej dla dotkniętych klęskami żywiołowymi części kontynentu. Gotowość do wykonywania takich zadań stanowi istotny element strategii USA. Amerykańska flota poniosła zasadniczy ciężar działań ratowniczych w pierwszych tygodniach po tragicznych w skutkach trzęsieniu ziemi i tsunami na Oceanie Indyjskim w grudniu 2004 r. Siły morskie Stanów Zjednoczonych jako jedyne posiadały wystarczające siły i środki, by udzielić tak szybkiej i kompleksowej pomocy terenom dotkniętym żywiołem. Był to swoisty pokaz potęgi amerykańskiej floty ${ }^{48}$.

Marynarka wojenna nie jest jedynym instrumentem promocji amerykańskich interesów w regionie. Równie istotne są działania dyplomatyczne. Stany Zjednoczone liczą na przychylność państw dążących do zrównoważenia rosnącej siły Chin. Kluczowym elementem w nowym układzie sił w Azji miałby być strategiczny sojusz USA z Indiami, który stanowiłby realną przeciwwagę dla chińskich ambicji. Mógłby też skupić wokół siebie małe i średnie państwa takie jak

${ }^{46}$ Są one częścią szerszego programu zbrojeniowego o nazwie Future Surface Combatant Program. Przewiduje on również budowę nowoczesnych krążowników i niszczycieli. Zob. B. Alkire, J. Birkler, L. Dolan, J. Dryden, B. Mason, G. Lee, J. Schank, M. Hayes, Littoral Combat Ships. Relating performance to mission package inventories, homeports, and installation sites, RAND Corp, Santa Monica 2007, s. 1-10. Nowoczesne okręty LCS wydają się przede wszystkim odpowiedzią na chińską doktrynę morską opartą na strategii „anty-dostępowej” (antiacces strategy). Polega ona na spowolnieniu rozmieszczenia amerykańskich jednostek na teatrze działań wojennych, uniemożliwieniu im operowania w pewnej części jego obszaru oraz zmuszeniu do działania z dystansu dalszego, niż ma to zwykle miejsce. Realizacja doktryny przewiduje m.in. użycia pocisków balistycznych z głowicami manewrującymi (w celu niszczenia lotniskowców) oraz środków wojny minowej.Zob. R. Cliff, M. Burles, M. Chase, D. Eaton, K. Pollpeter, Entering the Dragon's Lair. Chinese antiacces strategy and their implications for the United States, RAND Corp., Santa Monica 2007, passim.

${ }^{47}$ Nie można wykluczyć, że w obliczu drastycznych cięć budżetu obronnego USA, spowodowanych kryzysem gospodarczym, program rozwoju sił morskich może zostać zaniechany lub znacząco ograniczony. $Z$ pewnością cięcia przyczynią się do opóźnień we wdrażaniu nowych systemów uzbrojenia. Zob. W. Łuczak, Kryzys amerykańskich wydatków wojskowych, „Raport-wto” 2011, nr 12, s. 42-45.

${ }^{48}$ R. Kaplan, Monsoon: The Indian Ocean..., op. cit., s. 278. 
Wietnam, Indonezja czy Malezja. Symbolem tych dążeń jest wezwanie prezydenta Baracka Obamy do tego, by włączyć Indie w skład stałych członków Rady Bezpieczeństwa ONZ. Indie nigdy nie ukrywały swoich ambicji, ale dopiero teraz zyskały w tym względzie silny głos poparcia ze strony USA. Deklaracja prezydenta USA pojawiła się w czasie jego podróży po Azji, którą odbył w listopadzie 2010 r. Azjatycka wyprawa Baracka Obamy obowiązkowo obejmowała wizytę w Indiach, w której trakcie nakreślono główne kierunki rozwoju wzajemnych relacji ${ }^{49}$.

Historia stosunków indo-amerykańskich jest bardzo złożona. W okresie zimnowojennej rywalizacji mocarstw Indie były jednym z liderów Ruchu Państw Niezaangażowanych. W 1962 r. Stany Zjednoczone jednoznacznie potępiły chińską agresję na Indie. Pomimo politycznego wsparcia z ich strony państwo to ukierunkowało się na współpracę ze Związkiem Radzieckim, z którym łączył je podobny ustrój gospodarczy oraz nieufność wobec Chin. Czynnikiem negatywnie wpływającym na relację z Indiami był także sojusz z Pakistanem, który dla USA stanowił istotny element zimnowojennej rozgrywki. Również normalizacja stosunków z ChRL, poczynając od wizyty Richarda Nixona w Pekinie w 1972 r., wzbudziła w Indiach sporo obaw. Dzięki niej Chiny wyszły z międzynarodowej izolacji oraz uzyskały miejsce stałego członka RB ONZ, co niebywale wzmocniło to państwo.

To właśnie Chiny stanowią klucz do zrozumienia współczesnych stosunków indo-amerykańskich. ChRL jest dla Indii głównym rywalem w walce o uzyskanie pozycji regionalnego mocarstwa, jak również głównym konkurentem w wyścigu po surowce energetyczne, które napędzają gospodarki obu państw. Źródeł wzajemnej niechęci należy szukać również w sporze granicznym, który w 1962 r. zaowocował konfliktem zbrojnym. Chodzi o sporne obszary w pasie Himalajów i Karakorum. W wyniku wojny ChRL włączyła do swojego terytorium obszar Aksai Chin, łączący region autonomiczny Xinjiang z Tybebetem. Jest on uznawany przez Indie za część Kaszmiru. Chiny roszczą sobie również prawa do Północno-Wschodniego Obszaru Granicznego (NEFA) będącego częścią indyjskiej prowincji Arunachal Pradesh ${ }^{50}$. Wydarzenia z 1962 r. wywołały w Indiach szok, który skłonił przywódców państwa do przeorientowania dotychczasowych założeń geopolitycznych oraz nawiązania bliskiej współpracy wojskowej ze ZSRR. Chiny,

${ }^{49}$ S. Stolberg, J. Yardley, Countering China, Obama backs India for U.N. Council, „New York Times” z 09.11.2010 r.

${ }^{50} \mathrm{C}$. Bajpaee, China-India relations. Regional rivalry takes the world stage, „China Security" 2010, vol. 6, no. 2, s. 42-45. 
obok Pakistanu, uznane zostały za główne zagrożenie dla bezpieczeństwa państwa ${ }^{51}$. Z perspektywy amerykańskiej normalizacja stosunków z Chinami miała w okresie Zimnej Wojny ogromne znaczenie strategiczne. Wzmocnienie tego państwa miało zrównoważyć rosnące wpływy Związku Radzieckiego w Azji. Obecnie, gdy era zimnowojenna należy już do przeszłości, łatwiej budować sojusz indo-amerykański na kontynencie.

Problemem pozostaje nadal kwestia Pakistanu. Jest to kluczowy sojusznik Stanów Zjednoczonych w globalnej walce z terroryzmem po 11 września 2001 r. Stosunki z Pakistanem są jednak w równym stopniu wartościowe, co problematyczne. Indie oskarżają to państwo o wspieranie terroryzmu kaszmirskiego. Jednocześnie USA udzielają mu pomocy finansowej oraz sprzedają nowoczesne uzbrojenie ${ }^{52}$. Wyzwaniem dla dyplomacji amerykańskiej są również coraz większe wpływy Chin w Pakistanie. Stanowi to źródło niepokoju zarówna dla Indii, jak i Stanów Zjednoczonych ${ }^{53}$.

Punktem zwrotnym w procesie budowy strategicznego sojuszu z Indiami była umowa o współpracy w dziedzinie energetyki jądrowej z 2006 r. Ma ona ogromne znaczenie w kontekście rosnącego zużycia energii w Indiach ${ }^{54}$. W Stanach Zjednoczonych umowa była jednak źródłem silnych kontrowersji. Indie nie są bowiem stroną Układu o nieproliferacji (NPT) oraz Układu o całkowitym zakazie prób $\mathrm{z}$ bronią jądrową (CTBT), co do tej pory stanowiło konieczny warunek dla nawiązania tego typu współpracy z USA. Jest to precedens, który w istotny sposób osłabia reżim nieproliferacji broni jądrowej5. Decydujące w tej sprawie okazały się jednak geopolityczne interesy USA. Umowa została podpisana i zatwierdzona przez Kongres także dzięki kampanii, jaką w tej sprawie prowadziło silne i wpływowe lobby hinduskie działające w Stanach Zjednoczonych ${ }^{56}$.

${ }^{51}$ Por. S. Adhikari, A. Sinha, M. Kamle, India's changing geopolitical code: an attempt at analysis, "Geopolitics Quarterly" 2008, vol. 3, no 4, s. 15.

${ }^{52}$ K. A. Kronstadt, Pakistan-US relations, Congressional Research Service Report RL33498, Washington DC, 6 February 2009, s. 24-30, 57-61. http://www.fas.org/sgp/ crs/row/RL33498.pdf, 10.06.2011 r.

53 Por. R. Naseer, M. Amin, Sino-Pakistan relations. A natural alliance against common threats, „Berkeley Journal of Social Sciences” 2011, vol. 1, no. 2.

${ }^{54}$ H. Sokolski, Gauging US-Indian strategic cooperation, USAWC ISS, March 2007, s. 15-18.

55 Ibidem, s. 99-100; O. Meier, The US-India nuclear deal. The end of universal non-proliferation efforts ?, „Internationale Politik und Gesellschaft” 2006, $\mathrm{nr}$ 4, s. 2841. http://www.fes.de/ipg/inhalt_d/pdf/Meier_GB.pdf, 10.05.2011 r.

${ }^{56}$ Wpływy lobby hinduskiego w Stanach Zjednoczonych porównywane są często 
Współpraca w dziedzinie energetyki jądrowej z USA oznacza dla Indii przede wszystkim transfer nowoczesnych technologii, które dadzą temu państwu większe możliwości w zakresie produkcji energii elektrycznej. Indie potrzebują wsparcia technologicznego ze strony rozwiniętych państw zachodnich również w innych dziedzinach. Dotyczy to zarówno gałęzi cywilnych, jak i wojskowych. Siły zbrojne Indii i Chin funkcjonują głównie w oparciu o uzbrojenie i technologie wojskowe $\mathrm{z}$ dawnego ZSRR i Rosji. Oba państwa były przez długi czas największymi importerami rosyjskiej broni. We wrześniu $2001 \mathrm{r}$. Stany Zjednoczone i Unia Europejska zdjęły z Indii i Pakistanu embargo na dostawy uzbrojenia konwencjonalnego wprowadzone w $1998 \mathrm{r}$. w reakcji na testy nuklearne przeprowadzane przez te państwa ${ }^{57}$. Stawia to Indie w korzystniejszej niż Chiny sytuacji pod względem dostępu do nowoczesnych technologii wojskowych. Na ChRL nadal ciąży embargo na sprzedaż uzbrojenia nałożone na początku lat dziewięćdziesiątych przez USA i UE ${ }^{58}$.

z siłą organizacji proizraelskich. Obywatele USA pochodzenia hinduskiego stanowią najczęściej dobrze wykształconą, zamożną i świetnie zorganizowaną grupę, zdolną do wywierania skutecznego nacisku na instytucje polityczne tego państwa. Ich pozycję społeczną ilustruje fakt, iż ponad 20 proc. spółek ulokowanych w Dolinie Krzemowej należy do przedstawicieli tej mniejszości. J. Newhouse, Diplomacy, Inc. The influence of lobbies on U.S. foreign policy, „Foreign Affairs” 2009, vol. 88, no. 3, s. 81-84.

${ }_{57}$ W latach 1997-2001 37 proc. eksportowanego przez Rosję uzbrojenia trafiało do Chin i Indii. SIPRI Yearbook 2002: Armaments, Disarmament and International Security, Oxford 2002, s. 375-378. Otwarcie zachodniego przemysłu zbrojeniowego na Indie podkopuje dotychczasową silną pozycję Rosji na tym rynku. Stany Zjednoczone gotowe są zaoferować Indiom swoje najnowocześniejsze technologie wojskowe, do których do tej pory dostęp mieli jedynie najbliżsi sojusznicy Ameryki. Przykładem tego jest oferta sprzedaży najnowszego amerykańskiego myśliwca piątej generacji F-35 Lightning II. USA deklarują przy tym możliwość pełnego transferu, zastosowanych w maszynie, technologii. Zgoda Indii w praktyce oznaczać będzie rezygnację tego państwa z zakupu analogicznej konstrukcji rozwijanej we współpracy z Rosją o nazwie PAK FA (T-50). F-35 przeciwko PAK FA, „Raport-wto”, nr 11/2011, s. 70.

${ }^{5}$ Zakaz sprzedaży uzbrojenia do Chin był konsekwencją wydarzeń na placu Tiananmen z czerwca 1989 r. Po wprowadzeniu embarga Chiny mogły liczyć jedynie na dostawy ze strony rosyjskiej zbrojeniówki. W UE coraz częściej słychać głosy podważające zasadność dalszego utrzymywania embarga. Szczególnie zainteresowana jego zniesieniem jest Francja, która w 2004 roku, przy wsparciu Niemiec, wezwała do rewizji zakazu eksportu uzbrojenia do ChRL. SIPRI Yearbook 1995: Armaments, Disarmament and International Security, Oxford 1995, s. 506-507; K. Archick, R. Grimmett, S. Kan, European Union's arms embargo on China. Implications and options for U.S. policy, Congressional Research Service Report RL32870, Washington DC, 27 May 2005, s. 6-8, http://www.fas.org/sgp/crs/row/RL32870.pdf, 10.04.2011 r. 
Przewaga technologiczna jest wykorzystywana przez USA jako instrument promocji swoich interesów na kontynencie azjatyckim. Transfer technologii stanowi zachętę dla współpracy gospodarczej i politycznej ze Stanami Zjednoczonymi. USA posługują się tym narzędziem także w stosunku do Chin. Administracja B. Obamy aktywnie wspiera współpracę amerykańskich i chińskich firm energetycznych w zakresie eksploatacji złóż gazu łupkowego w Chinach. Uzyskanie technologii pomagających w produkcji czystej energii pozwoli Chinom zredukować emisję dwutlenku węgla do atmosfery oraz częściowo pokryje rosnące zapotrzebowanie tego państwa na energię59. Ograniczenie zużycia surowców energetycznych pochodzących z importu poprawi również poziom bezpieczeństwa energetycznego Chin, a przez to korzystnie wpłynie na ogólną sytuację polityczną w regionie.

W obliczu rosnącej siły azjatyckich wschodzących mocarstw Stany Zjednoczone starają się wdrożyć nową strategię wobec tego regionu. Mają do dyspozycji szereg narzędzi. Wykorzystując potęgę militarną, wpływy dyplomatyczne oraz przewagę technologiczną starają się wpływać na układ sił w regionie Oceanu Indyjskiego. Nie ulega wątpliwości, że głównym celem USA jest zbudowanie nieformalnego sojuszu, w celu zrównoważenia rosnącej siły Chin. Jest to warunek niezbędny dla dalszej obecności Stanów Zjednoczonych w Azji.

\section{Podsumowanie}

REgion OcEAnu IndyJSKiego STANOWi obecnie pole intensywnej rywalizacji wschodzących mocarstw Chin i Indii. Oba państwa odgrywają coraz większą rolę w gospodarce światowej wiodąc prym w produkcji przemysłowej. Wraz ze wzrostem gospodarczym demonstrują one również coraz większą asertywność w polityce zagranicznej. Chiny i Indie aspirują do miana mocarstw regionalnych, konsekwentnie rozszerzając swoje strefy wpływów w Azji. Proces ten wymaga od nich utrzymania wysokiego i nieprzerwanego wzrostu gospodarczego. Podstawową wadą ich gospodarek jest jednak wysoka energochłonność, która prowadzi do coraz większego uzależniania się od importu surowców energetycznych. Obszar Azji Południowej ma dla nich kluczowe znaczenie w zakresie pozyskiwania oraz transportu węglowodorów. Rywalizacja obu państw w tym względzie odbywa się zarówno na płaszczyźnie poli-

${ }^{59}$ U.S.-China Joint Statement, The White House - Office of the Press Secretary, November 17, 2009, http://www.whitehouse.gov/the-press-office/us-china-jointstatement, 14.04.2011 r. 
tycznej, gospodarczej i wojskowej. Przyjęte przez nie strategie skupiają się na zabezpieczeniu swoich interesów poprzez agresywną działalność inwestycyjną koncernów energetycznych, rozbudowę morskich sił zbrojnych oraz ochronę szlaków komunikacyjnych o strategicznym znaczeniu.

Rosnące znaczenie Chin i Indii niesie ze sobą istotne implikacje geopolityczne dla Stanów Zjednoczonych, które przeżywają w tym czasie poważny kryzys ekonomiczny. Szczególne obawy w USA budzi wzrost siły i pozycji Chin na obszarze zachodniego Pacyfiku, z którego państwami łączy je szereg więzów sojuszniczych oraz gospodarczych. Ich strategia polega w największym stopniu na budowie sojuszu stanowiącego przeciwwagę dla chińskiej dominacji. Twardym jądrem tego sojuszu mają być stosunki z Indiami. Stany Zjednoczone starają się wspierać to państwo zarówno na polu wojskowym i gospodarczym. Umocnienie sojuszników pozwoli USA na przeniesienie dużej części odpowiedzialności za sprawy bezpieczeństwa w regionie na ich barki.

Wynik geopolitycznej gry, która toczy się na kontynencie azjatyckim, w dużej mierze zadecyduje o przyszłym kształcie ładu międzynarodowego. W Azji bije obecnie serce globalnej gospodarki. Wyhamowanie państw zachodnich i wzrost gospodarek wschodzących oznacza całkowitą zmianę w układzie sił na świecie. Zmiany, które zachodzą w regionie Oceanu Indyjskiego w widoczny sposób obrazują ten proces.

\section{SUMMARY}

The Indian OcEAN CONSTITUTES AN AREA WHICH IS RICH in resources and vital to shipping. In this region there are some strategic sealines that enable communication of China and India with this resourceful area. Due to the fact that the Indian Ocean region is rich in oil, China and India seek dominance in this part of the world. The article explains and describes the dynamic of greatpower rivalry in various aspects. It also analyzes the role of the Unites States as stabilizing power in the new political and economic environment in Asia.

\section{Nota O AUTORZE}

Maciej Karczewski [maciej.karczewski@amu.edu.pl] - absolwent Wydziału Nauk Politycznych i Dziennikarstwa oraz Wydziału Histo- 
rycznego na Uniwersytecie im. Adama Mickiewicza w Poznaniu. Obecnie doktorant na WNPiD UAM. Zainteresowania naukowe obejmują tematykę związaną z bezpieczeństwem międzynarodowym, kwestiami zbrojeń i rozbrojenia oraz naturą konfliktów zbrojnych. 